\title{
Plant Regeneration through Callus Cultures from Leaf Explant of Sumatra Benzoin (Styrax benzoin)
}

\author{
Isnaini Nurwahyuni $\mathbb{D}^{1},{ }^{1}$ Manihar Situmorang, ${ }^{2}$ and Riyanto Sinaga ${ }^{1}$ \\ ${ }^{1}$ Department of Biology, Faculty of Mathematics and Natural Sciences, Universitas Sumatera Utara, \\ Jl. Bioteknologi No. 1 Padang Bulan, Medan, North Sumatera 20155, Indonesia \\ ${ }^{2}$ Department of Chemistry, Faculty of Mathematics and Natural Science, Universitas Negeri Medan, Jl. Willem Iskandar, Psr V, \\ Medan, North Sumatera 20221, Indonesia \\ Correspondence should be addressed to Isnaini Nurwahyuni; isnaininurwahyuni@yahoo.co.id
}

Received 20 April 2020; Revised 16 September 2020; Accepted 21 September 2020; Published 1 October 2020

Academic Editor: Anna Źróbek-Sokolnik

Copyright (c) 2020 Isnaini Nurwahyuni et al. This is an open access article distributed under the Creative Commons Attribution License, which permits unrestricted use, distribution, and reproduction in any medium, provided the original work is properly cited.

\begin{abstract}
Micropropagation of Sumatra Benzoin is potential to provide good-quality seed for future preservation of the forest and improve the incense sap production. The production of Styrax plants is currently limited by the availability of seed. This research demonstrated the micropropagation of Sumatra Benzoin (Styrax benzoin Dryander), producing good-quality saplings that could be used for obtaining nontimber forest products. Elite mother plant was selected and used as a source of explants. Identification of healthy trees was carried out based on the phenotype criteria, and the selection of a mother plant was performed through information on the quality and quantity production of incense sap. Micropropagation started from callus induction in young leaves followed by subculture to obtain regeneration of shoots and roots. The combination of NAA and BAP in the culture media greatly affected the growth and development of callus, shoots, and roots. The use of $3 \mathrm{mg} / \mathrm{L}$ NAA and $3 \mathrm{mg} / \mathrm{L}$ NAA rendered the heaviest calli. Shoots were regenerated with $0.5 \mathrm{mg} / \mathrm{L} \mathrm{NAA}$ and $3.0 \mathrm{mg} / \mathrm{L} \mathrm{BAP}$, and the highest growth of roots was obtained by using of $3.0 \mathrm{mg} / \mathrm{NAA}$ without BAP. This research reports the first in vitro propagation technique for Styrax benzoin. Further research is underway to obtain very good-quality plant saplings to be used for forest conservation and to increase the production of incense sap as a nontimber forest commodity.
\end{abstract}

\section{Introduction}

Indonesia is a tropical region with big forest areas that are sources of global oxygen. To improve the quality of Indonesian forest is necessary to produce high-value nontimber forest products. Highly productive trees will become an alternative commodity to the farmers around the forest area, as instead of being logged they will protect the forest areas and increase the welfare of the community [1-6]. One of the candidate plants to be preserved is Sumatra Benzoin (Styrax benzoin Dryander). Sumatra benzoin is grouped to division Spermatophyte, subdivision Angiospermae, class Dicotyledonae, order Ebenales, family Styracaceae, genus Styrax, and species Styrax benzoin Dryander. The benzoin trees grow well in the forest area in North Sumatera and produce a high-quality incense sap, known as frankincense.

The styrax sap contains bioactive compounds that can be used in various purposes such as medical and cosmetics ingredients in modern and traditional medicine [7, 8]. Tapping of incense is the main livelihood for some residents at villages close to the forest area at Kabupaten Pakpak Bharat, North Sumatera Indonesia (Hotdi Berutu 2019: personal communication). The propagation of Sumatra Benzoin plants in Indonesia is generally carried out through seeds that grow naturally in the forest. This strategy makes it difficult to obtain uniform seedlings that produce goodquality incense sap, as some of the trees produce high quantity of gum resin while some other produce low 
amount. Besides, it takes around 10 years for naturally growing plants to produce sap. The production of incent sap possibly would lower down in the future if there is no action being carried out to replant the forest with good-quality saplings. These two problems can be overcome through the production of good saplings via micropropagation from high-quality mother plants. Micropropagation is an appropriate choice for the multiplication of plants, since it allows the production of uniform saplings true-to-type to the mother plant in large quantities and at a relatively short time [9-11], but to the best of our knowledge it has not been applied to Sumatra Benzoin. Micropropagation can be done from various types of explants obtained from a mother plant, namely, seeds, young leaves, petioles, stem segments, axillary shoots, apical or axillary meristems, etc. [12-15]. The composition of the culture medium influences the growth development of the plant [16-19]. Therefore, factors like explant source, growth regulators, mineral nutrients, and incubation conditions should be optimized when propagating valuable plants [20-23], and these factors need to be considered in the propagation of Benzoin plants. The purpose of this study is to apply the micropropagation technique to selected Sumatra Benzoin (Styrax benzoin Dryander) plants, in an effort to produce good-quality saplings that produce frankincense in large quantities and with the same quality as the mother plant. The saplings are expected to be planted in tropical forests as a strategy to preserve the forest and to improve nontimber forest product. Good-quality saplings are intended to be distributed for plantation of industrial forest and replantation of deforestated field in local area at Kabupaten Pakpak Bharat, North Sumatera, Indonesia.

\section{Materials and Methods}

Micropropagation was carried out at Department of Biology, Faculty of Mathematics and Natural Science, Universitas Sumatera Utara, and at the forest area at Kecamatan Sitellu Tali Urang Julu, Kabupaten Pakpak Bharat, North Sumatera, Indonesia. The area is distributed into eight districts (Kecamatan) and fifty-three villages (Desa). Two villages at Kecamatan Sitellu Tali Urang Julu were chosen, namely, Desa Lae Lange Namuseng and Desa Rumerah, since they bear a virgin forest with the most extensive forest land with a relatively large number of naturally grown Sumatra Benzoin populations.

2.1. Identification and Selection of Mother Plant Trees. Exploration for the Sumatra Benzoin trees was carried out at different and random forest locations with the guide of experience farmers. Healthy Benzoin trees were selected based on the verbal information given by the farmers on the quality and quantity production of incense sap accompanied by scientific judgements. The information for the productivity of incent sap was evaluated based on the estimated amount of gum harvested through traditional techniques at a harvest period in a year. The selection of the target plants was done based on the quantity and quality productions of incense sap in the past three years. Healthy plants that produced a large quantity of sap and good-quality incense sap were marked as potential source of explants for the micropropagation technique. The survey result for Sumatra Benzoin is summarized in Table 1.

Sixty-two mature and productive plants have been identified in the forest area as possible mother plants; twenty-three trees from among these trees produced large quantities of incense sap with very good quality, but only one of the best trees was selected as the source of explants in micropropagation in further research. The selected Sumatra Benzoin plants are about 10 years old, healthy, having dense leaves, fertile, and producing high quantity of incense gum. The average height of healthy plants is about 5-10 meters, with an average stem diameter of $20-40 \mathrm{~cm}$.

2.2. Preparation of Culture Medium. The culture medium used in this study was Murashige and Skoog (MS) medium [24] containing of $30 \mathrm{~g} / \mathrm{L}$ sucrose and complete nutrients of macro, micro, and trace elements, supplemented with the growth regulators $\alpha$-naphthaleneacetic acid (NAA) and benzyl amino purine (BAP). After adjusting the $\mathrm{pH}$ of the solution to 5.8 , the medium was sterilized at $121^{\circ} \mathrm{C}$ for 20 minutes. The concentration of growth regulators varied by using $0,1,2$, and $3 \mathrm{mg} / \mathrm{L}$ of BAP and NAA, in a two-factorial experiment as shown in Table 2 [25]. The container used was a $50 \mathrm{~mL}$ bottle containing $15 \mathrm{~mL}$ of media. One explant was planted in each bottle and five replications were made in all experiments.

\subsection{Explant Preparation and Micropropagation Procedures.} Young leaves, shoot tips, and seeds were collected from selected plants. Young leaves and shoots were cleaned and sterilized, and the hard shells of the seeds were peeled to obtain the embryos for further sterilization. For sterilization, the explants were rinsed with a fungicide solution $(2 \mathrm{~g} / \mathrm{L}$ Dithane), followed by cleaning with running water. The explants were then cut into pieces $(0.5-1.0 \mathrm{~cm})$, washed successively with distilled water and detergent, rinsed in flow water, followed by dipping in ethanol (70\%) for 5 minutes, and rinsed with distilled water. They were then dipped in hypochlorite solution $(0.8 \% \mathrm{w} / \mathrm{v} \mathrm{NaOCl})$ for 20 minutes and rinsed with sterile water. The explants were inoculated in MS media supplemented with growth regulators of NAA and BAP as described in Table 1 . To eliminate fungal and bacterial contamination, the laminar air flow and the room were sterilized using a UV-C lamp $(\lambda 280 \mathrm{~nm})$ for 16 hours. The cultures were incubated at $25 \pm 2^{\circ} \mathrm{C}$. The culture environment in the growth room and the flow cabinet was regularly sprayed with $70 \%$ alcohol to maintain sterile conditions. Subculturing was carried out to initiate plants from callus. Seven-week-old calli were transferred to culture media containing the same growth regulators levels and the same environmental conditions as in the callus induction procedure. Data collection to measure the size and weight of callus was carried out after seven weeks of incubation. Plant growth and development such as the number of shoots and roots were counted after an incubation time of 12 weeks. The 
TABle 1: The description of Sumatra Benzoin (Styrax benzoin Dryander) selected as mother plants trees in the forest area at District Sitellu Tali Urang Julu.

\begin{tabular}{|c|c|c|c|c|}
\hline \multirow{2}{*}{ No. } & \multirow{2}{*}{ Plant parameter } & \multirow{2}{*}{$\begin{array}{c}\text { General } \\
\text { conditions }\end{array}$} & \multicolumn{2}{|c|}{ Location of selected mother plant* } \\
\hline & & & Desa Lae Lange Namuseng & Desa Rumerah \\
\hline 1 & $\begin{array}{l}\text { Frequency of selected Styrax benzoin plants per hectare of } \\
\text { forest }\end{array}$ & Total 62 & $27 / 12$ & $35 / 11$ \\
\hline 2 & $\begin{array}{c}\text { Plant appearance based on visual identification and } \\
\text { scientific judgement }\end{array}$ & Vary & $\begin{array}{l}22 \text { plants fertile and healthy } \\
\text { and } 5 \text { less fertile plants }\end{array}$ & $\begin{array}{l}29 \text { plants fertile and healthy } \\
\text { and } 6 \text { less fertile plants }\end{array}$ \\
\hline 2 & $\begin{array}{l}\text { Gum production (based on verbal information on the } \\
\text { quality and quantity production of incense sap given by } \\
\text { the farmers every harvest time) }\end{array}$ & Vary & $\begin{array}{l}12 \text { plants with high- } \\
\text { quantity and good-quality } \\
\text { incense sap }\end{array}$ & $\begin{array}{l}11 \text { plants with high- } \\
\text { quantity and good-quality } \\
\text { incense sap }\end{array}$ \\
\hline 3 & $\begin{array}{c}\text { Plant categories based on maturity level (age 8-15 years } \\
\text { old) }\end{array}$ & Mature & $\begin{array}{l}\text { Stem diameter } 20-40 \mathrm{~cm} \\
\text { and tree height } 5-10 \mathrm{~m}\end{array}$ & $\begin{array}{l}\text { Stem diameter } 20-40 \mathrm{~cm} \\
\text { and tree height } 5-15 \mathrm{~m}\end{array}$ \\
\hline 4 & Soil location and conditions where the plants grows & Vary & $\begin{array}{l}\text { Some plant and mostly hilly } \\
\text { forest areas }\end{array}$ & All are hilly forest areas \\
\hline
\end{tabular}

* Plant samples that have fulfilled the requirements for mother plants to be used as source of explant in the micropropagation of Sumatra Benzoin.

TABLE 2: The experimental design for micropropagation of Sumatra Benzoin (Styrax benzoin Dryander) in MS medium with $\alpha$-naphthaleneacetic acid and benzyl amino purine.

\begin{tabular}{cccccc}
\hline \multicolumn{5}{c}{ BAP (mg/L) } \\
\hline & & 0 & 1 & 2 & 3 \\
NAA (mg/L) & 0 & $\mathrm{~A}_{0} \mathrm{~B}_{0}$ & $\mathrm{~A}_{0} \mathrm{~B}_{1}$ & $\mathrm{~A}_{0} \mathrm{~B}_{2}$ & $\mathrm{~A}_{0} \mathrm{~B}_{3}$ \\
& 1 & $\mathrm{~A}_{1} \mathrm{~B}_{0}$ & $\mathrm{~A}_{1} \mathrm{~B}_{1}$ & $\mathrm{~A}_{1} \mathrm{~B}_{2}$ & $\mathrm{~A}_{1} \mathrm{~B}_{3}$ \\
& 2 & $\mathrm{~A}_{2} \mathrm{~B}_{0}$ & $\mathrm{~A}_{2} \mathrm{~B}_{1}$ & $\mathrm{~A}_{2} \mathrm{~B}_{2}$ & $\mathrm{~A}_{2} \mathrm{~B}_{3}$ \\
& 3 & $\mathrm{~A}_{3} \mathrm{~B}_{0}$ & $\mathrm{~A}_{3} \mathrm{~B}_{1}$ & $\mathrm{~A}_{3} \mathrm{~B}_{2}$ & $\mathrm{~A}_{3} \mathrm{~B}_{3}$ \\
\hline
\end{tabular}

$\mathrm{NAA}=$ naphthalene acetic acid. $\mathrm{BAP}=$ benzylaminopurine.

superiority of plants based on the quantity of production and the quality of the sap determines the selection of the best mother plant. In vitro propagation data were callus weight, shoot development, and root growth due to variations in experimental treatments. Data were analyzed statistically using ANOVA followed by Duncan's multiple range analysis $(P=0.05)[25]$.

\section{Results}

3.1. Micropropagation of Sumatra Benzoin. The propagation of Sumatra Benzoin was carried out through callus initiation that was subcultured to induce shoots and roots, with the final goal of obtaining plantlets. Young leaf explants, shoots, and seed embryos were taken from the best-quality mother plants. The explants of young leaves that just grew on the branches of the plant produced the highest callus weight with high growth intensity with minimal fungal contamination. The explants from shoots and seed embryos also produced callus. Leaf explants from flowering branches were also used but they did not produce callus and were always contaminated, probably due to having been exposed for a long time to fungi in the forest. Selecting explants from young leaves is a strategy to reduce fungal contamination, especially when using plant material harvested directly from the forest.

Micropropagation of Sumatra Benzoin at the subculture stage is shown in Figure 1. Seven-week-old callus (Figure 1(a)) was subcultured in the medium at various concentrations of growth regulators (Figure 1(b)). Callus regeneration occurred after six weeks, followed by shoot formation after 12 weeks (Figure 1(c)) and root shoots (plantlets) (Figure 1(d)). The variation in the combination of the concentration of growth regulators affects the intensity of growth and development of the Sumatra Benzoin plant.

3.2. Optimization of Callus Induction. The initial stage of Sumatra Benzoin micropropagation was callus induction. The responses of young leaves, shoot tips, and embryos are summarized in Table 3. Leaf explants that had been exposed to the forest environment for a long time only enlarged in the first week then became filled with fungi due to contamination. Young leaves were selected in this study due to their ability to produce aseptic cultures and a relatively high callus growth.

The concentration of growth regulators affected callus growth, which increased when the explants were supplemented with very high concentrations of BAP or NAA and the combination of both (Table 3 ). When young leaves were used, most of the explants (76.25\%) produced callus, although their sizes were variable (Table 4). There were explants (23.75\%) which enlarged without callus formation, or did not grow and experienced browning (although the incubation time was extended for a long time), possibly due to the oxidation of polyphenols in the explant cells [26]. The effects of concentration of BAP or NAA on the weight of callus are summarized in Table 4 . Callus weight increased with the concentration of growth regulators, and the highest values were obtained in the $\mathrm{A}_{3} \mathrm{~B}_{3}$ treatment $(388 \pm 30 \mathrm{mg}$ ) supplemented with $3 \mathrm{mg} / \mathrm{L}$ NAA and $3 \mathrm{mg} / \mathrm{L}$ BAP. Callus weight was significantly increased in the treatment group with increasing concentrations of benzylaminopurine in the media.

3.3. Plantlet Production. The production of Styrax benzoin Dryander plants was carried out through successive subculturing by using the same concentration of growth regulators as in callus initiation. The growth and development of shoots and roots of Styrax benzoin Dryander after 12 weeks is presented in Table 5 . The subculture technique was very effective to induce shoots of Sumatra Benzoin, and the number of shoots was strongly influenced by the growth regulators in the media. In comparison, the calli that were 


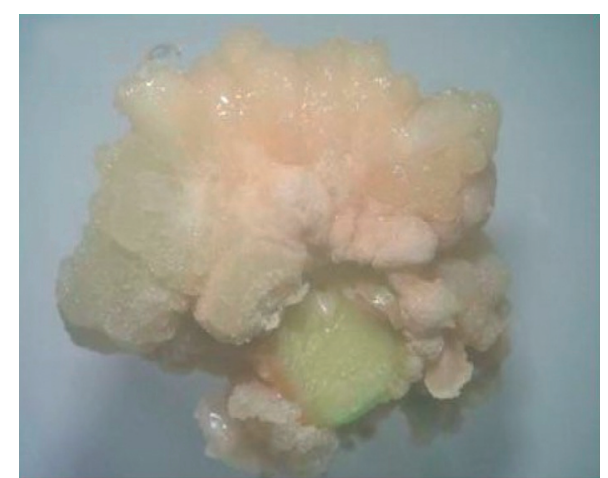

(a)

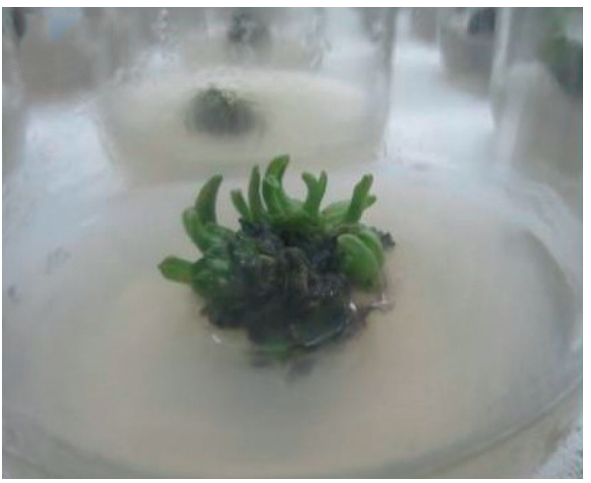

(c)

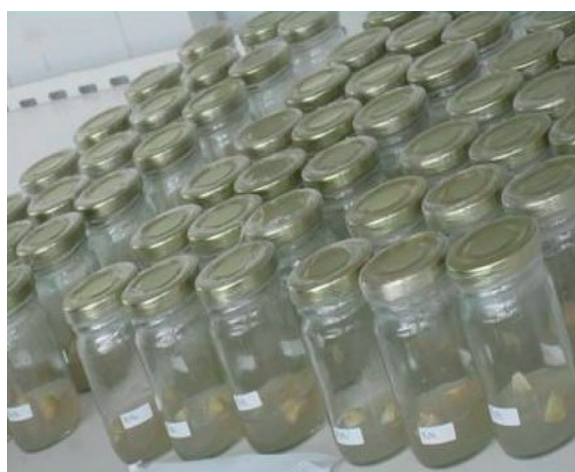

(b)

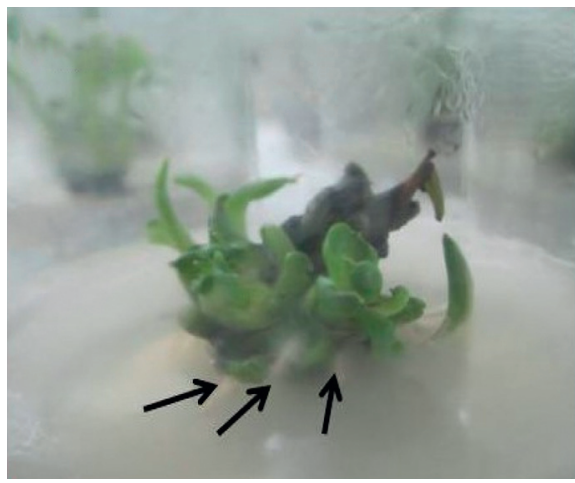

(d)

Figure 1: Micropropagation of Sumatra Benzoin by callus subculture from young leaf explants. (a) Seven-week-old callus. (b) Callus subculture in the media. (c) Regeneration into shoots. (d) Planlets (arrow showing root growth) after incubation for 12 weeks.

TABle 3: Development of callus of Styrax benzoin Dryander after seven weeks of culture (treatments are specified in Table 2).

\begin{tabular}{|c|c|c|c|c|}
\hline \multirow[t]{2}{*}{ Treatments } & \multicolumn{4}{|c|}{$\begin{array}{l}\text { Callus development and growth on various types } \\
\text { of explants }\end{array}$} \\
\hline & Young leaves & Shoot tips & Embryo & Leaves \\
\hline $\mathrm{A}_{0} \mathrm{~B}_{0}$ & $*$ & $*$ & $*$ & $* *$ \\
\hline $\mathrm{A}_{0} \mathrm{~B}_{1}$ & + & + & + & $* *$ \\
\hline $\mathrm{A}_{0} \mathrm{~B}_{2}$ & ++ & + & ++ & $* *$ \\
\hline $\mathrm{A}_{0} \mathrm{~B}_{3}$ & +++ & ++ & ++ & $* *$ \\
\hline $\mathrm{A}_{1} \mathrm{~B}_{0}$ & + & + & + & $* *$ \\
\hline$A_{1} B_{1}$ & ++ & + & + & $* *$ \\
\hline$A_{1} B_{2}$ & +++ & ++ & +++ & $* *$ \\
\hline$A_{1} B_{3}$ & ++ & + & + & $* *$ \\
\hline $\mathrm{A}_{2} \mathrm{~B}_{0}$ & + & + & + & $* *$ \\
\hline $\mathrm{A}_{2} \mathrm{~B}_{1}$ & ++ & + & + & $* *$ \\
\hline $\mathrm{A}_{2} \mathrm{~B}_{2}$ & + & + & + & $* *$ \\
\hline $\mathrm{A}_{2} \mathrm{~B}_{3}$ & ++ & + & + & $* *$ \\
\hline $\mathrm{A}_{3} \mathrm{~B}_{0}$ & +++ & ++ & +++ & $* *$ \\
\hline $\mathrm{A}_{3} \mathrm{~B}_{1}$ & + & + & + & $* *$ \\
\hline $\mathrm{A}_{3} \mathrm{~B}_{2}$ & ++ & + & ++ & $* *$ \\
\hline $\mathrm{A}_{3} \mathrm{~B}_{3}$ & +++ & ++ & +++ & $* *$ \\
\hline
\end{tabular}

* The explant enlarge without callus, ${ }^{+}$low callus growth, ${ }^{++}$medium callus growth, ${ }^{+++}$high callus growth, and $* *$ contamination.

not subcultured were incubated in the media for up to 12 weeks. This procedure produced very large callus that almost covered the entire surface of the explants but did not produce plantlets. The effect of BAP and NAA and their combination onto the growth of plant shoots is summarized
TABLE 4: Growth and development of callus of Styrax benzoin Dryander from young leaves after seven weeks of culture.

\begin{tabular}{lcc}
\hline Treatments & \multicolumn{2}{c}{$\begin{array}{c}\text { Callus } \\
\text { Weight of callus/explant } \\
(\mathrm{mg})^{*}\end{array}$} \\
\hline $\mathrm{A}_{0} \mathrm{~B}_{0}$ & 79.81 & $18 \pm 9^{\mathrm{f}}$ \\
$\mathrm{A}_{0} \mathrm{~B}_{1}$ & 75.19 & $34 \pm 11^{\mathrm{ef}}$ \\
$\mathrm{A}_{0} \mathrm{~B}_{2}$ & 75.09 & $36 \pm 11^{\mathrm{ef}}$ \\
$\mathrm{A}_{0} \mathrm{~B}_{3}$ & 69.85 & $38 \pm 9^{\text {ef }}$ \\
$\mathrm{A}_{1} \mathrm{~B}_{0}$ & 79.82 & $44 \pm 11^{\mathrm{ef}}$ \\
$\mathrm{A}_{1} \mathrm{~B}_{1}$ & 75.33 & $46 \pm 11^{\mathrm{ef}}$ \\
$\mathrm{A}_{1} \mathrm{~B}_{2}$ & 79.76 & $62 \pm 9^{\text {ef }}$ \\
$\mathrm{A}_{1} \mathrm{~B}_{3}$ & 80.21 & $68 \pm 9^{\text {ef }}$ \\
$\mathrm{A}_{2} \mathrm{~B}_{0}$ & 75.11 & $46 \pm 18^{\mathrm{de}}$ \\
$\mathrm{A}_{2} \mathrm{~B}_{1}$ & 74.88 & $84 \pm 11^{\mathrm{de}}$ \\
$\mathrm{A}_{2} \mathrm{~B}_{2}$ & 79.74 & $90 \pm 14^{\mathrm{de}}$ \\
$\mathrm{A}_{2} \mathrm{~B}_{3}$ & 80.02 & $114 \pm 11^{\mathrm{cd}}$ \\
$\mathrm{A}_{3} \mathrm{~B}_{0}$ & 75.15 & $180 \pm 24^{\mathrm{b}}$ \\
$\mathrm{A}_{3} \mathrm{~B}_{1}$ & 70.08 & $196 \pm 23^{\mathrm{b}}$ \\
$\mathrm{A}_{3} \mathrm{~B}_{2}$ & 74.68 & $240 \pm 14^{\mathrm{b}}$ \\
$\mathrm{A}_{3} \mathrm{~B}_{3}$ & 75.31 & $388 \pm 30^{\mathrm{a}}$ \\
$\mathrm{Average}$ & 76.25 & $106 \pm 14$ \\
\hline
\end{tabular}

The experiments were conducted with five replicates. Treatments are described in Table 2. ${ }^{*}$ Data shown are mean of five explants. Treatments followed by a different letter are significant according to Duncan's multiple range analysis $(P=0.05)$.

in Table 5. Approx. $42 \%$ of calli produced shoots, and the highest number of shoots was obtained in the group of $A_{1} B_{3}$ $(3.63 \pm 0.54$ shoots). Calli that were not treated with BAP or 
Table 5: Regeneration of shoots and roots in Styrax benzoin Dryander calli obtained from young leaves after 12 weeks of culture.

\begin{tabular}{|c|c|c|c|c|}
\hline \multirow[b]{2}{*}{ Treatments } & \multicolumn{2}{|c|}{ Shoots } & \multicolumn{2}{|c|}{ Roots } \\
\hline & Explants with shoots (\%) & $\begin{array}{l}\text { Average number of shoots/ } \\
\text { explants* }\end{array}$ & Explants with roots (\%) & $\begin{array}{c}\text { Average number of roots/ } \\
\text { explants* }\end{array}$ \\
\hline $\mathrm{A}_{0} \mathrm{~B}_{0}$ & - & $0.00^{\mathrm{e}}$ & 60.12 & $0.54 \pm 0.01^{\mathrm{ef}}$ \\
\hline $\mathrm{A}_{0} \mathrm{~B}_{1}$ & 59.81 & $1.18 \pm 0.16^{\mathrm{d}}$ & 69.24 & $0.54 \pm 0.01^{\mathrm{ef}}$ \\
\hline $\mathrm{A}_{0} \mathrm{~B}_{2}$ & 70.06 & $1.92 \pm 0.62^{b c}$ & - & $0^{\text {ef }}$ \\
\hline $\mathrm{A}_{0} \mathrm{~B}_{3}$ & 60.22 & $1.95 \pm 1.31^{\mathrm{b}}$ & - & $0^{\text {ef }}$ \\
\hline $\mathrm{A}_{1} \mathrm{~B}_{0}$ & - & $0.00^{\mathrm{e}}$ & 75.15 & $2.59 \pm 0.05^{\mathrm{cd}}$ \\
\hline $\mathrm{A}_{1} \mathrm{~B}_{1}$ & 60.12 & $1.77 \pm 1.18^{\mathrm{cd}}$ & 70.25 & $2.96 \pm 0.06^{\mathrm{bcd}}$ \\
\hline $\mathrm{A}_{1} \mathrm{~B}_{2}$ & 69.76 & $2.96 \pm 0.79^{\mathrm{abc}}$ & 70.06 & $1.35 \pm 0.03^{\mathrm{de}}$ \\
\hline $\mathrm{A}_{1} \mathrm{~B}_{3}$ & 75.05 & $3.63 \pm 0.54^{\mathrm{a}}$ & 70.05 & $4.58 \pm 0.09^{\mathrm{abc}}$ \\
\hline $\mathrm{A}_{2} \mathrm{~B}_{0}$ & - & $0.00^{\mathrm{e}}$ & 70.16 & $2.37 \pm 0.05^{\mathrm{cd}}$ \\
\hline $\mathrm{A}_{2} \mathrm{~B}_{1}$ & - & $0.00^{\mathrm{e}}$ & 70.34 & $2.96 \pm 0.06^{\mathrm{bcd}}$ \\
\hline $\mathrm{A}_{2} \mathrm{~B}_{2}$ & 69.85 & $1.59 \pm 0.16^{\mathrm{bc}}$ & 70.23 & $1.35 \pm 0.03^{\mathrm{de}}$ \\
\hline $\mathrm{A}_{2} \mathrm{~B}_{3}$ & 70.18 & $2.75 \pm 0.67^{\mathrm{ab}}$ & 69.65 & $1.88 \pm 0.04^{\mathrm{de}}$ \\
\hline $\mathrm{A}_{3} \mathrm{~B}_{0}$ & - & $0.00^{\mathrm{e}}$ & 70.38 & $5.92 \pm 0.12^{\mathrm{a}}$ \\
\hline $\mathrm{A}_{3} \mathrm{~B}_{1}$ & - & $0.00^{\mathrm{e}}$ & 60.05 & $5.03 \pm 0.10^{\mathrm{ab}}$ \\
\hline $\mathrm{A}_{3} \mathrm{~B}_{2}$ & 59.72 & $1.08 \pm 0.72^{\mathrm{e}}$ & 69.65 & $2.96 \pm 0.06^{\mathrm{bcd}}$ \\
\hline $\mathrm{A}_{3} \mathrm{~B}_{3}$ & 70.15 & $2.32 \pm 0.20^{\mathrm{abc}}$ & 69.63 & $1.62 \pm 0.03^{\mathrm{de}}$ \\
\hline Average & 41.56 & $1.32 \pm 0.40$ & 60.31 & $2.62 \pm 0.05$ \\
\hline
\end{tabular}

The experiments were conducted with five replicates. Experimental treatments are described in Table $2 .{ }^{*}$ Data shown are mean of five replicates followed by different letters are significant according to Duncan's multiple range analysis $(P=0.05)$.

NAA did not produce shoots. The combination of BAP and NAA in the media was determinant for shoot induction. Low concentrations of BAP and NAA stimulated the growth of shoots to some extent, whereas the combination of high NAA and BAP concentrations did not induce shoots in some cases. High concentrations of BAP ( $3 \mathrm{mg} / \mathrm{L})$ stimulated the induction of shoots of Styrax benzoin Dryander. However, increasing the concentration of NAA at low BAP concentrations did not increase the number of shoots in the culture.

The concentration of growth regulators greatly affected the number of roots (Table 5). The results showed that the majority of calli produce roots $(60.31 \%)$. The concentration of BAP and NAA in medium culture influenced the root growth, with the highest levels found in the $A_{3} B_{0}$ group (average $5.92 \pm 0.12$ roots).

\section{Discussion}

A survey has successfully been carried out to identify goodquality Styrax benzoin Dryander trees and to select the best mother plant as the source of explants for in vitro plant propagation. Information provided by farmers were very relevant in determining the quality of the trees. A total of 23 Styrax benzoin Dryander trees were identified as qualified mother plants, and one of the best plants was used as the source of explants in micropropagation technique. The best plant is about 10 years old, stem diameter $30 \mathrm{~cm}$, height $10 \mathrm{~m}$, very dense, the bark is healthy and relatively not moldy, and it has a lot of incense sap production with very good quality.

Micropropagation of Sumatra Benzoin has been carried out by using explants from the best mother plant. In vitro propagation of Sumatra Benzoin was carried out in an effort to get the same high-quality plant as the mother plant.
Selection of explants from young leaves in micropropagation has been successful in reducing fungal contamination of culture media $[27,28]$. Explants originating from leaves that had long been spilled in the forest environment were very difficult to be freed from fungal contamination although very strict sterilization has been conducted. The strategy of selecting explants from young leaves and shoots that have just grown on mature tree branches and the inside of the seeds of the plant proved to be minimum from fungal contamination; however, explants of young leaves became the choice in this study due to higher response to callus initiation. To the best of our knowledge, there are not reports on the micropropagation of Sumatra Benzoin; therefore, the optimization of growth regulators to obtain optimum conditions for the development of this plant represents an advance in this subject. NAA and BAP concentrations influenced callus production and the regeneration of shoots and roots. The optimal callus production was obtained by using very high concentrations of $3 \mathrm{mg} / \mathrm{L} \mathrm{NAA}$ and $3 \mathrm{mg} / \mathrm{L}$ $\mathrm{BAP}$ in the $\mathrm{A}_{3} \mathrm{~B}_{3}$ group. The growth trend of callus induction found in the propagation of Sumatra Benzoin plants is similar as that previously reported in studies on other woody plants [29, 30].

The strategy plant seedling has been carried out through subculture of the callus. Shoots and roots have been successfully induced at this stage, but no leaves could be induced so far. The highest shoot regeneration was obtained by using a combination of low concentration of $0.5 \mathrm{mg} / \mathrm{L}$ NAA with high concentration of $3.0 \mathrm{mg} / \mathrm{L} \mathrm{BAP}$ in the $\mathrm{A}_{1} \mathrm{~B}_{3}$ group. Meanwhile, the best condition for producing roots was to use high concentration $3.0 \mathrm{mg} / \mathrm{L}$ NAA without BAP in the $A_{3} B_{0}$ group. These results indicate that the ratio of NAA and BAP concentrations is crucial in inducing Sumatra Benzoin plantlets. BAP functions as an NAA antagonist in root formation, as previously reported [31-34]. This study 
provides the first insight into the micropropagation of Benzoin Sumatra, and more research is needed to optimize the combination of growth regulators for leaf induction and the production of whole Sumatran Benzoin plants. Micropropagation of Styrax benzoin Dryander is indeed very difficult, but the results obtained at this stage are very promising because they have produced shoots and roots and hope that they will develop into plants. Further research is underway to obtain good-quality and uniform Styrax benzoin Dryander saplings for forest conservation purposes and to increase the production of sap as a source of bioactive compounds of high economic value $[35,36]$.

\section{Conclusion}

This study provides the first insight into the in vitro culture of the Sumatran Benzoin tree. Young leaves of mature trees were treated with several combinations of NAA and BAP. The optimal condition for inducing callus was using high concentrations of NAA and BAP $(3 \mathrm{mg} / \mathrm{L})$. The highest number of shoots was obtained with a low concentration NAA $(0.5 \mathrm{mg} / \mathrm{L})$ and a high concentration of BAP $(3.0 \mathrm{mg} /$ $\mathrm{L})$, whereas the addition of $3 \mathrm{mg} / \mathrm{L}$ NAA without BAP stimulated rooting. These results demonstrate the feasibility of obtaining shoot and root regeneration of Styrax benzoin to a certain extent, although more research is being conducted to achieve leaf development and plant production. The present study demonstrated the potential for success in plant propagation of this species in an effort to obtain goodquality plant saplings that will be used to conserve forests and to increase the production of incense sap as a nontimber forest commodity.

\section{Data Availability}

The data are available in the corresponding author's laboratory record at the Department of Biology, Faculty of Mathematics and Natural Science, Universitas Sumatera Utara, Indonesia.

\section{Conflicts of Interest}

The authors declare that there are no conflicts of interest regarding the publication of this work.

\section{Acknowledgments}

The funding support for this research was obtained from the Directorate Research and Community Service, Directorate General Strengthen Research and Development, Ministry of Research, Technology and Higher Education of the Republic of Indonesia, Financial Year 2019, under Penelitian Dasar Unggulan Perguruan Tinggi (PDUPT) (Contract no. 147/ UN5.2.3.1/PPM/KP/DRPM/2019). The help from Hotdi Berutu and Tambun Berutu at Kecamatan Sitellu Tali Urang Julu and Kabupaten Pakpak Bharat is gratefully acknowledged, for guiding the research team in the forest area and giving adequate information on the techniques of tapping the incense sap. The authors also acknowledge Dr. Isli Iriani
Pane from the Language Centre of Universitas Negeri Medan who had helped in the English proofreading process.

\section{References}

[1] A. T. Jarangchi and L. Sangma, "Non-timber forest products (NTFPs) used by garo tribe of rongram block in West Garo Hills, Meghalaya," Indian Journal of Traditional Knowledge, vol. 18, no. 1, pp. 151-161, 2019.

[2] J. Wu, W. Lin, X. Peng, and W. Liu, "A review of forest resources and forest biodiversity evaluation system in China," International Journal of Forestry Research, vol. 2013, Article ID 396345, 7 pages, 2013.

[3] T. van den Boog, J. Bulkan, J. Tansey, and T. R. van Andel, "Sustainability issues of commercial non-timber forest product extraction in West Suriname," Journal of Ethnobiology and Ethnomedicine, vol. 14, no. 1, p. 44, 2018.

[4] D. K. Langat, E. K. Maranga, A. A. Aboud, and J. K. Cheboiwo, "Role of forest resources to local livelihoods: The Case of East Mau Forest Ecosystem, Kenya," International Journal of Forestry Research, vol. 2016, Article ID 4537354, 10 pages, 2016.

[5] L. Chinangwa, A. S. Pullin, and N. Hockley, "Livelihoods and welfare impacts of forest comanagement," International Journal of Forestry Research, vol. 2016, Article ID 5847068, 12 pages, 2016.

[6] S. Boadi, M. Baah-Acheamfour, F. Ulzen-Appiah, and G. M. Jamro, "Nontimber forest product yield and income from Thaumatococcus daniellii under a mixed tree plantation system in Ghana," International Journal of Forestry Research, vol. 2014, Article ID 524863, 8 pages, 2014.

[7] S. Ashfaq, M. Ahmad, M. Zafar, S. Sultana, S. Bahadur, and N. Abbas, "Medicinal plant biodiversity used among the rural communities of arid regions of northern Punjab, Pakistan," Indian Journal of Traditional Knowledge, vol. 18, no. 2, pp. 226-241, 2019.

[8] C. Fan, H. Jin, L. Wu et al., "An exploration of traditional Chinese medicinal plants with anti-inflammatory activities," Evidence-Based Complementary and Alternative Medicine, vol. 2017, Article ID 1231820, 10 pages, 2017.

[9] S. Shinde, J. K. Sebastian, J. R. Jain, M. S. Hanamanthagouda, and H. N. Murthy, "Efficient in vitro propagation of Artemisia nilagirica var. nilagirica (Indian wormwood) and assessment of genetic fidelity of micropropagated plants," Physiology and Molecular Biology of Plants, vol. 22, no. 4, pp. 595-603, 2016.

[10] P. Baskaran, A. Kumari, and J. V. Staden, "In vitro propagation via organogenesis and synthetic seeds of Urginea altissima (L. f.) Baker: a threatened medicinal plant," 3 Biotech, vol. 8, no. 1, p. 18, 2017.

[11] K. Wu, S. Zeng, D. Lin et al., "In vitro propagation and reintroduction of the endangered Renanthera imschootiana Rolfe," PLoS One, vol. 9, no. 10, Article ID e110033, 2014.

[12] X. Zhang, J. Zhao, J. A. T. da Silva, and G. Ma, "In vitro plant regeneration from nodal segments of the spontaneous F1 hybrid Santalum yasi $\times$ S. album and its parents $S$. album and S. yasi," Trees, vol. 30, pp. 1983-1994, 2016.

[13] M. S. Shekhawat, M. Manokari, and C. P. Ravindran, "Micropropagation, micromorphological studies, and in vitro flowering in Rungia pectinata L.," Scientifica, vol. 2016, Article ID 5813851, 7 pages, 2016.

[14] S. E. Rozali, K. A. Rashid, and R. M. Taha, "Micropropagation of an exotic ornamental plant, Calathea crotalifera, for production of high quality plantlets," The Scientific World Journal, vol. 2014, Article ID 457092, 12 pages, 2014. 
[15] M. U. Yildirim, "Micropropagation of Origanum acutidens (HAND.-MAZZ.) IETSWAART using stem node explants," The Scientific World Journal, vol. 2013, Article ID 276464, 3 pages, 2013.

[16] K. A. Quiroz, M. Berríos, B. Carrasco, J. B. Retamales, P. D. S. Caligari, and R. García-Gonzáles, "Meristem culture and subsequent micropropagation of Chilean strawberry (Fragaria chiloensis (L.) Duch.)," Biological Research, vol. 50, no. 1, 2017.

[17] I. Nurwahyuni, H. N. Marpaung, and S. Rahayu, "In vitro germination of anti-diabetic plant loquat (Eriobotrya japonica Lindl.) to produce good seedling (Funded work)," International Journal of Pharma and Bio Sciences, vol. 8, no. 4, pp. 30-39, 2017.

[18] Y. Cui, Y. Deng, K. Zheng et al., "An efficient micropropagation protocol for an endangered ornamental tree species (Magnolia sirindhorniae Noot. \& Chalermglin) and assessment of genetic uniformity through DNA markers," Scientific Reports, vol. 9, no. 1, p. 9634, 2019.

[19] A. A. Alatar, M. Faisal, E. M. Abdel-Salam et al., "Efficient and reproducible in vitro regeneration of Solanum lycopersicum and assessment genetic uniformity using flow cytometry and SPAR methods," Saudi Journal of Biological Sciences, vol. 24, no. 6, pp. 1430-1436, 2017.

[20] I. Nurwahyuni and R. Sinaga, "In vitro propagation of threatened brastagi citrus variety brastepu (Citrus nobilis brastepu) free CVPD through shoot tips subculture," Pakistan Journal of Botany, vol. 50, no. 2, pp. 667-678, 2018.

[21] B. Thiem, M. Kikowska, M. P. Maliński, D. Kruszka, M. Napierała, and E. Florek, "Ecdysteroids: production in plant in vitro cultures," Phytochemistry Reviews, vol. 16, no. 4, pp. 603-622, 2017.

[22] P. F. de Oliveira, J. L. Damasceno, C. S. Bertanha, A. R. B. Araújo, P. M. Pauletti, and D. C. Tavares, "Study of the cytotoxic activity of Styrax camporum extract and its chemical markers, egonol and homoegonol," Cytotechnology, vol. 68, no. 4, pp. 1597-1602, 2016.

[23] M. Soni and R. Kaur, "Rapid in vitro propagation, conservation and analysis of genetic stability of Viola pilosa," Physiology and Molecular Biology of Plants, vol. 20, no. 1, pp. 95-101, 2014.

[24] T. Murashige and F. Skoog, "A revised medium for rapid growth and bio assays with tobacco tissue cultures," Physiologia Plantarum, vol. 15, no. 3, pp. 473-497, 2006.

[25] J. H. Zar, Biostatistical Analysis: Pearson New International Edition, Pearson Education Ltd., London, UK, 5th edition, 2014.

[26] P. A. Roussos and C. A. Pontikis, "Phenolic compounds in olive explants and their contribution to browning during the establishment stage in vitro," Gartenbauwissenschaft, vol. 66, no. 6, pp. 298-303, 2001.

[27] C. A. Ozel, K. M. Khawar, and F. Unal, "Factors affecting efficient in vitro micropropagation of Muscari muscarimi Medikus using twin bulb scale," Saudi Journal of Biological Sciences, vol. 22, no. 2, pp. 132-138, 2015.

[28] S.-L. Chen, H. Yu, H.-M. Luo, Q. Wu, C.-F. Li, and A. Steinmetz, "Conservation and sustainable use of medicinal plants: problems, progress, and prospects," Chinese Medicine, vol. 11, p. 37, 2016.

[29] M. K. Cheruvathur and T. D. Thomas, "High frequency multiple shoot induction from nodal segments and rhinacanthin production in the medicinal shrub Rhinacanthus nasutus (L.) Kurz," Plant Growth Regulation, vol. 74, no. 1, pp. 47-54, 2014.
[30] D. Doric, V. Ognjanov, M. Ljubojevic et al., "Rapid propagation of sweet and sour cherry rootstocks," Notulae Botanicae Horti Agrobotanici Cluj-Napoca, vol. 42, no. 2, pp. 488-494, 2014.

[31] H. Y. Park, K. W. Kang, D. H. Kim, and I. Sivanesan, "In vitro propagation of Cymbidium goeringii Reichenbach fil. through direct adventitious shoot regeneration," Physiology and Molecular Biology of Plants, vol. 24, no. 2, pp. 307-313, 2018.

[32] J. S. Yaacob, N. Mahmad, R. M. Taha, N. Mohamed, A. I. M. Yussof, and A. Saleh, "Optimization of culture conditions (sucrose, $\mathrm{pH}$, and photoperiod) for in vitro regeneration and early detection of somaclonal variation in ginger lime (Citrus assamensis)," The Scientific World Journal, vol. 2014, Article ID 262710, 9 pages, 2014.

[33] T. D. Nikam, R. P. Ghorpade, K. M. Nitnaware, M. L. Ahire, V. H. Lokhande, and A. Chopra, "Micropropagation and non-steroidal anti-inflammatory and anti-arthritic agent boswellic acid production in callus cultures of Boswellia serrata Roxb," Physiology and Molecular Biology of Plants, vol. 19, no. 1, pp. 105-116, 2013.

[34] A. J. Debnath, G. Gangopadhyay, D. Basu, and S. R. Sikdar, "An efficient protocol for in vitro direct shoot organogenesis of Sesamum indicum L. using cotyledon as explant," 3 Biotech, vol. 8, no. 3, p. 146, 2018.

[35] I. Nurwahyuni and R. Sinaga, "In vitro propagation for bioconservation of threatened Brastagi citrus in North Sumatra Indonesia," International Journal of Pharma and Bio Sciences, vol. 5, no. 4, pp. B863-B873, 2014.

[36] A. A. Mozafari, Y. Vafaee, and E. Karami, "In vitro propagation and conservation of Satureja avromanica Maroofi-an indigenous threatened medicinal plant of Iran," Physiology and Molecular Biology of Plants, vol. 21, no. 3, pp. 433-439, 2015. 